\title{
FISSIDENS LINEARIS \\ (FISSIDENTACEAE: BRYOPHYTA) A NEW RECORD FOR INDIA
}

\author{
K. M. Manjula ${ }^{1}$, C. N. Manju ${ }^{1,2 *}$, V. K. Rajilesh ${ }^{2}$ and V. K. Chandini ${ }^{1}$ \\ ${ }^{1}$ Department of Botany, The Zamorin's Guruvayurappan College, Calicut, Kerala, India \\ *E-mail:manjucali@gmail.com \\ ${ }^{2}$ Malabar Botanical Garden, Olavvana, Kozhikode-14, Kerala, India
}

(Received 23 May, 2014; Accepted 1 September, 2014)

Fissidens linearis var. obscurirete, is reported as a new record of occurrence to India from the Western Ghats of Kerala.

Key words: Fissidens linearis var. obscurirete, Fissidentaceae, India, Kerala, new record, Western Ghats

\section{INTRODUCTION}

The genus Fissidens is a widely distributed species (Imura and Iwatsuki 1988, Ishihara and Iwatsuki 1992, Iwatsuki et al. 1999, Wijk et al. 1962, 1969). From India more than 100 species have been reported, but now only 78 of them are validly accepted (Dandotiya et al. 2011, Daniels 2010, Frahm et al. 2013, Gangulee 1969, Manju et al. 2008, Verma et al. 2011). During the field trip through the Western Ghats, we could collect an interesting species of Fissidens from the Western Ghats of Marayur of Idukki District and Agasthyamalai of Thiruvananthapuram District of Kerala. On detailed examination it proved as Fissidens linearis, which was not recorded earlier from India. F. linearis includes four varieties, as var. aeruginosus, var. angustifolius, var. linearis and var. obscurirete. The present collection shows similarity with var. obscurirete. This variety is earlier known from China, Japan, Korea, Taiwan and New Caledonia. This species is described here with its variety obscurirete as new record for India. 


\section{Fissidens linearis var. obscurirete Broth. et Paris}

(Fig. 1)

Fissidens linearis var. obscurirete Broth. et Paris in Brotherus, Oefv. Finsk. Vet. Soc. Foerh. 51: 7. 1909.

=F. micro-serratus Sak., Bot. Mag. Tokyo 47: 738. 1933.

=F. nitidocostatus Toy., Acta Phytotax. Geobot. 4: 215, f. 3. 1935.

=F. tokioensis Sak., Bot. Mag. Tokyo 51: 8, f. 1. 1937.

=F. jinguensis Sak., Bot. Mag. Tokyo 65: 90, f. 1. 1952.

Plants small, 2-6 mm long, 1-1.7 mm wide including leaves, tip curled inwards when dry, 7-17 pairs of leaves, alternate, more crowded towards tip, usually unbranched with yellowish green coloured stem. Leaves lanceolate,
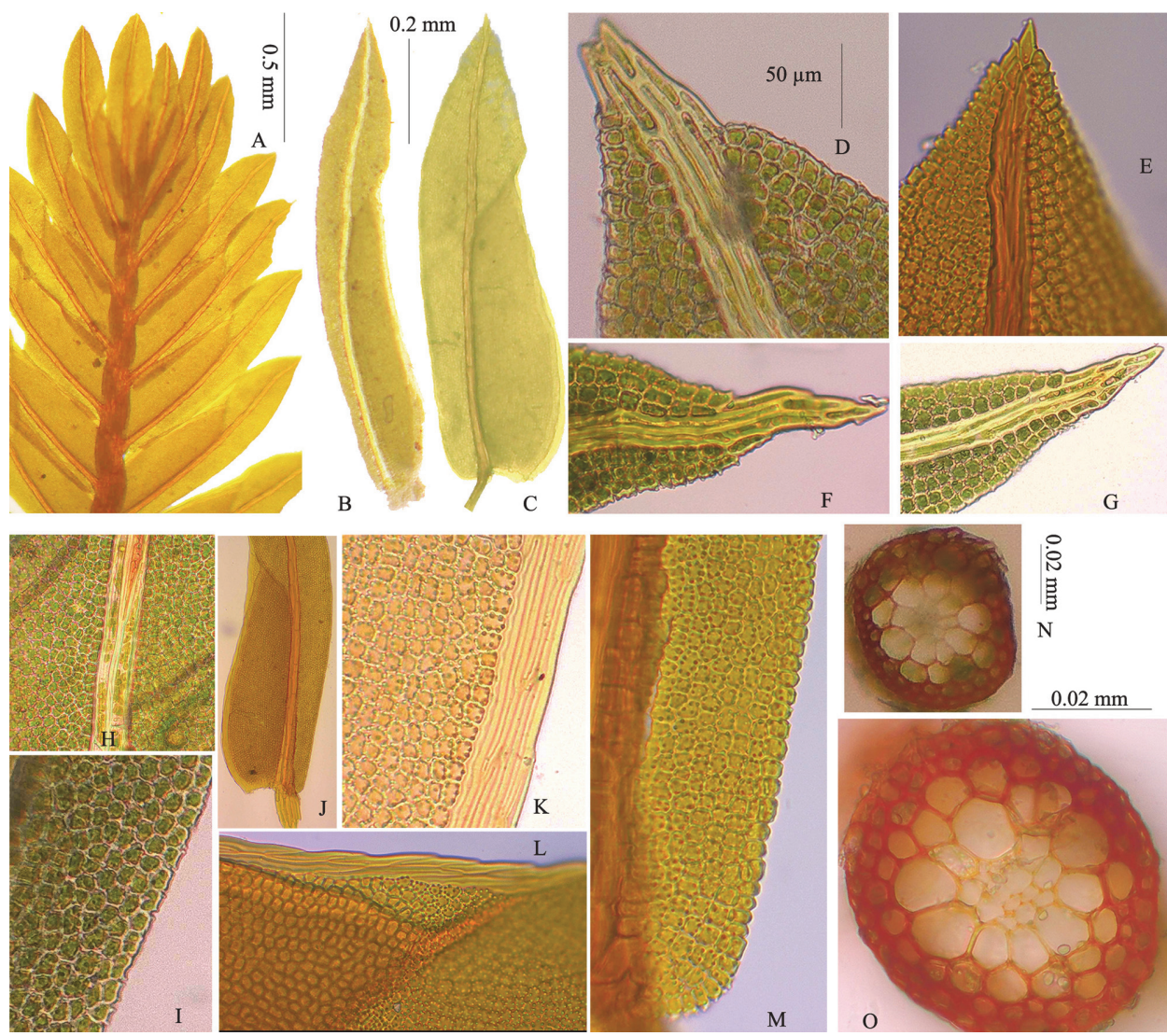

Fig. 1. Fissidens linearis var. obscurirete. $\mathrm{A}=$ habit-tip; $\mathrm{B}-\mathrm{C}=$ leaf; $\mathrm{D}-\mathrm{G}=$ leaf tip variations; $\mathrm{H}=$ leaf middle cells; $\mathrm{I}=$ leaf middle marginal cells; $\mathrm{J}=$ sheathing lamina; $\mathrm{K}=$ limbidium; $\mathrm{L}=$ apical lamina and sheathing lamina joining; $\mathrm{M}=$ dorsal lamina base; $\mathrm{N}-\mathrm{O}=$ cross section of stem (B-C and J same size; D-I and K-M same size) 
acute to narrowly acute at apex, $0.85-1.2 \mathrm{~mm}$ long, lower part $0.21-0.29 \mathrm{~mm}$ wide, $0.13-0.31 \mathrm{~mm}$ wide at upper part, lower leaves small or reduced, longer than wide, sheathing lamina open, unequal, reaches half the length of apical lamina, dorsal lamina base round, wedge shaped, margin of apical and dorsal lamina finely crenulate by projection of multipapillate cells; costa prominent, yellowish green, percurrent to shortly excurrent; cells compactly arranged, quadrate to irregularly hexagonal, multipapillate, cells at base of sheathing lamina elongate, smooth, limbidia found only on sheathing lamina of upper and perichaetial leaves, usually on the lower half, limbidia hyaline, elongate, smooth with $1-4$ rows, tip cells $20 \times 5 \mu \mathrm{m}$, lower cells $5-10 \times 3.75-5 \mu \mathrm{m}$; stem $0.12-0.14 \mathrm{~mm}$ in diameter, central strand lacking, marginal cells coloured, $3.75-5 \times 7.5 \mu \mathrm{m}$, inner cells large, 7.5-17.5 × 12.5-22.5 $\mu \mathrm{m}$. Sporophyte not observed.

Microhabitat: On roots of higher plants along the tea plantation and on earth bank.

Distribution: China, Japan, Korea, Taiwan, New Caledonia, India (Kerala: present collection).

Specimens examined: Kerala, Idukki, way to Munnar from Marayur (1,200 m), coll.: Manjula and Chandini (996), 05.02.2014 (ZGC); Thiruvananthapuram, Agasthyamalai Biosphere Reserve (1300 m), coll.: Rajilesh (732a), 12.12.2013 (MBG).

Acknowledgements - The authors are thankful to the SERB, DST (Department of Science and Technology) New Delhi for the financial support as Fast track Scheme. Rajilesh is thankful to the Kerala State Council for Science Technology \& Environment (KSCSTE) for the financial support. We are thankful to the authorities of the Zamorin's Guruvayurappan College (ZGC), Kozhikode and Malabar Botanical Garden for providing support and facilities. Thanks are also due to the officials of the Kerala Forest Department, for the permission and support extended during the field studies.

\section{REFERENCES}

Dandotiya, D., Govindapyari, H., Suman, S. and Uniyal, P. L. (2011): Checklist of the bryophytes of India. - Archive for Bryology 88: 1-126.

Daniels, A. E. D. (2010): Checklist of the bryophytes of Tamil Nadu, India. - Archive for Bryology 65: 1-118.

Frahm, J. P., Schwarz, U. and Manju, C. N. (2013): A checklist of mosses of Karnataka, India. - Archive for Bryology 158: 1-15.

Gangulee, H. C. (1969): Mosses of Eastern India and adjacent regions - a monograph. Vol. I. BSI, Calcutta.

Imura, S. and Iwatsuki, Z. (1988): Vegetative diasporas of genus Fissidens Hedw. (Fissidentaceae, Musci) in Japan. - Hikobia 10: 225-229. 
Ishihara, M. I. and Iwatsuki, Z. (1992): Some important sporophytic characters for infrageneric classification of the genus Fissidens. - Hikobia 11: 141-146.

Iwatsuki, Z., Suzuki, T. and Li, X. J. (1999): New records of Fissidens (Fissidentaceae, Bryopsida) in China. - Bryobrothera 5: 127-130.

Manju, C. N., Rajesh, K. P. and Madhusoodanan, P. V. (2008): Checklist of the bryophytes of Kerala, India. - Tropical Bryology Research Reports 7: 1-24.

Verma, P. K., Alam, A. and Srivastava, S. C. (2011): Status of mosses in Nilgiri Hills (Western Ghats), India. - Archive for Bryology 102: 1-13.

Wijk, V. R., Margadant, W. D. and Florschut, P. A. (1962): Index Muscorum. Vol. II. - International Association for Plant Taxonomy, Utrecht.

Wijk, V. R., Margadant, W. D. and Florschut, P. A. (1969): Index Muscorum. Vol. V. - International Association for Plant Taxonomy, Utrecht. 